\title{
Developing a framework for managing household debt The case of South Africa
}

\author{
Roseline Tapuwa Karambakuwa \\ Ronney Ncwadi \\ Nelson Mandela University \\ Department of Economics \\ Faculty of Business and Economic Sciences, South Africa
}

\section{Keywords}

South Africa, household, debt, income, consumption

\begin{abstract}
The proportion of household debt to disposable income is very high in South Africa, signifying over-indebtedness which reduces the welfare of households and ultimately reduces economic growth. This paper presents the determinants of the household debt in South Africa and comes up with a framework of recommendations on how to manage household debt. The objectives are achieved through systematic literature review, document analysis and secondary data analysis. Our findings suggest that households are over-indebted because they lack the necessary finance management skills, lack proper protection from the predatory practices by lenders and fail to obtain disclosure of vital information pertaining credit which affects their decision to borrow. Household indebtedness is also caused by the rising cost of living and low household disposable income, low household savings, high interest rates, misfortunes or adverse trigger events and living in urban areas. Education, age and being a recipient of a social grant all have positive and negative impacts on household indebtedness. Findings also suggest that female-headed households, renting households, large households, households with a mortgage and households where head is not working, is sick or disabled are more likely to be over-indebted. We develop a framework with recommendations for managing household debt in South Africa. We recommend upskilling to help households to effectively manage their finances and take responsibility. Moneylending institutions are encouraged to disclose vital information pertaining credit which affects decision to borrow by households and to avoid predatory lending. We also recommend a review of interest rates on debt and availability of consumption insurance on all loans to cover for cases when the household faces unforeseen circumstances affecting repayment.
\end{abstract}

Acknowledgements

This research was funded by National Research Foundation (NRF) South Africa.

\section{Introduction}

Household debt is beneficial to families as it enables them to buy goods and services that they would not be able to pay for in one go, raising their standard of living. They therefore smoothen their consumption over time providing stability to the economy (Harari, 2018). However, when households fail to repay their loans with commercial banks and other money lending institutions, it poses a threat to the wellbeing of the whole economy as the funds are taken from savings and the banks would in turn fail to honour their obligations to depositors (Zimunya \& Raboloko, 2015). In the financial sector household debt increases non-performing loans and weakens balance sheets of financial intermediaries and reduces availability of credit ultimately resulting in fall of household consumption (Albuquerque \& Krustev, 2015). In South Africa, there has been continued increase in household debt coupled with a high debt to income ratio and growth in repayment default, posing a challenge to the credit sector and the stability of the economy. Rises in debt levels increase borrowers' likelihood to default and leads to irregular financial cycles essentially risking the financial system collapse similar to what happened in the 2007-2009 global financial crisis (Klein, 2015).

The objectives of the paper are therefore to understand the nature and determinants of household debt and to come up with a framework for managing the household debt in South Africa. This will ensure reduction of debt burden amongst households and reduce the negative impact of excessive debt on the 
economy. Further, the government of South Africa provides social security grants to vulnerable households, yet a significant number of families still borrow large amounts of money, leading to high debt burden. This paper highlights impact of these grants on household debt. Our findings suggest that households are over-indebted because they lack the necessary financial management skills necessary to practice responsible spending and lack proper protection from the predatory practices by lenders at the same time. The increasing cost of living coupled with low household disposable income leads to low or no savings leading to increased household debt. Other causes of over-indebtedness are high interest rates on loans and misfortunes or adverse trigger events. Household debt is also affected by educational level, gender, age, health and employment status of the household head. Other determinants are whether the household is renting, has a mortgage, is a recipient of a social security grant or is large.

\section{South Africa's household debt}

According to Allen, Babus \& Carletti (2009), household debt has been associated with many financial crises and recessions. South Africa experienced a significant increase in its household debt to income ratio from the beginning of the financial crisis of 2008-2009 Meniago, Mukuddem-Petersen, Petersen \& Mongale (2013). South Africa's middle class is facing a massive debt problem, many people are borrowing to pay for necessities such as food and transport while on average those in bad debt spend $63 \%$ of their after-tax income on repayments (Business Tech, 2018). The worst first-time credit defaults for personal loans in South Africa are mainly young or single co-habiting couples reliant on social grants in one or two roomed informal dwellings (Business Tech, 2018). Table 1 shows composition of debt in South Africa with Mortgages constituting the majority, $52 \%$ of debt and short-term credit being the least at $0.2 \%$.

\begin{tabular}{|l|l|}
\hline Mortgages & $52 \%$ \\
\hline Secured credit agreements & $22 \%$ \\
\hline Credit facilities & $13 \%$ \\
\hline Unsecured credit & $10 \%$ \\
\hline Developmental credit & $2 \%$ \\
\hline Short-term credit & $0.2 \%$ \\
\hline
\end{tabular}

Table 1: Composition of debt in South Africa

Source: (National Credit Regulator (2016a)

Most of the household debt is from the banking sector at $83 \%$, retailers at $2 \%$, nonbank financiers at $5 \%$ and other credit providers at 10\% (National Credit Regulator, 2016a). Unsecured loans grew in South Africa by more than 53\% between 2010 and 2011 (National Credit Regulator (NCR) (2012). Unsecured debt has increased faster than household disposable income, and this has raised concerns among policy makers. This has caused concern for policymakers as the unsecured loans continue to increase faster than disposable income per household (Mutero, 2014). South Africa's household sector's debt level reached $86.4 \%$ of personal disposable income in 2008 following the global financial crisis (Trading Economics, 2020). However, the ratio of household debt to disposable income decreased slowly to $74.7 \%$ in the first quarter of 2012 (Meniago et al., 2013). It however fell to 79.8\% in 2011 and to 78,5\% in 2015 reaching 71.9 in 2018. In 2020 the ratio had increased to $77.1 \%$ and is now on an upward trajectory as shown on Figure 1. 
Figure 1: South Africa Household Debt to Income Ratio

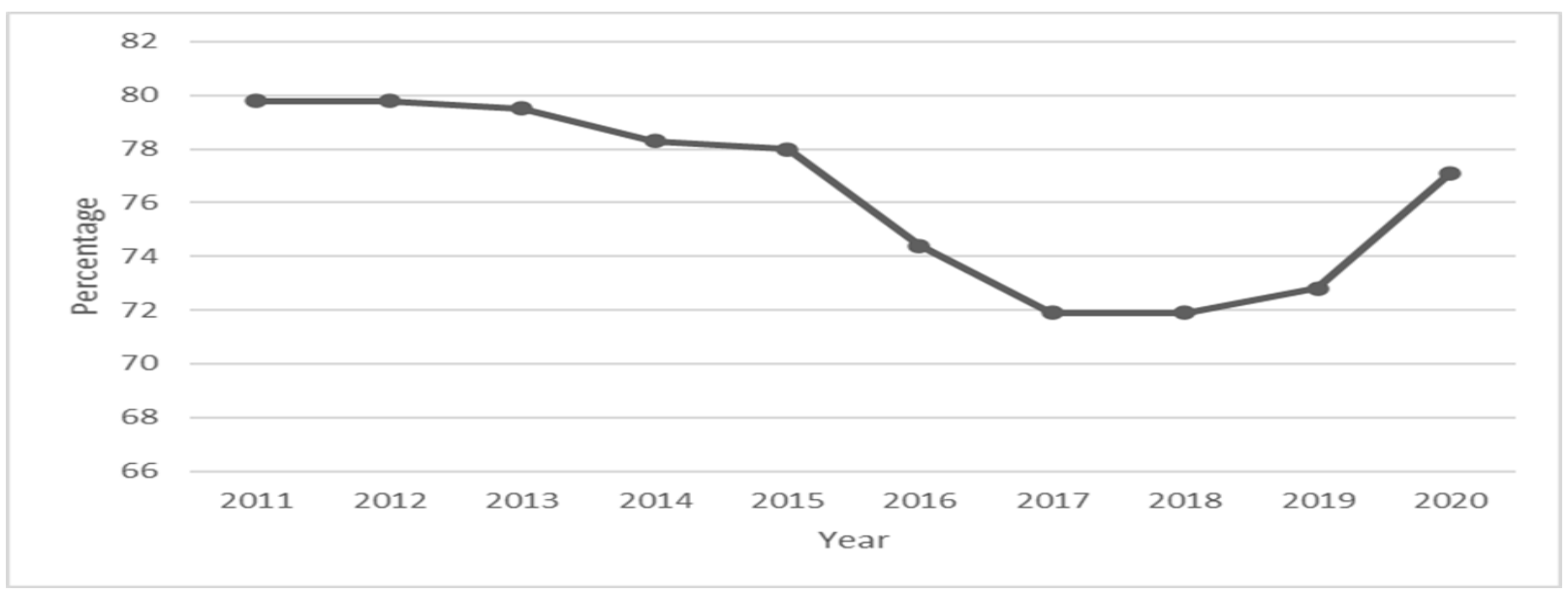

Source: Trading Economics (2020)

Both demand and supply side factors account for the high household debt in South Africa. These include overall decrease in interest rates, greater financial inclusion post-independence, lack of financial education and debt contracts that are vague and reckless lending by financial intermediaries (Hurwitz \& Luiz, 2007; National Credit Regulator, 2012). The indebtedness of households in South Africa has been worsened by natural disasters such as drought and floods and pandemics such as the HIV - AIDS and recently the coronavirus pandemic. These have caused reduced capacity to repay loans as people's capacity to generate income has been drastically reduced. Further, South Africa is amongst the countries with the highest income inequalities in the world and income inequality exacerbates the household debt problem (Barba \& Pivetti, 2009). There are macroeconomic variables such as consumption, housing prices, interest rates, inflation rates, economic growth, unemployment rates and money supply that determine the growth of household debt (Petersen, \& Mongale, 2013). Managing household debt given these aspects is therefore necessary for poverty reduction and economic growth.

South Africa was found to have the lowest number of economically literate people, and second lowest number of financially literate people from a survey of 50 countries, highlighting a serious problem of lack of necessary skills and knowledge to manage finances (Jappelli, 2010). The National Credit Act (NCA) No. 34 (2005) was implemented in South Africa for the National Credit Regulator (NCR) to provide consumers with the required skills and knowledge to understand the ever-changing financial market, protect already over-indebted households and prevent reckless credit granting (NCA, 2005). Several programmes and initiatives were implemented to educate citizens on making wise financial choices, to avoid being indebted and to seek assistance if already in debt (NCR, 2012). Despite some criticism on NCR effectiveness in training, it may not be realistic for it to provide the necessary financial training to all South Africans as all industry stakeholders need to assist and households need to take the responsibility (Seane, Mah and Saah 2016).

Extremely high household debt can have potential negative effects on the strength of households as they are left with less disposable income (Harari, 2018). The higher the proportion of disposable income individuals pay towards their debt, the less they would be able to save, leaving the households vulnerable and poorer. It also leaves less funds for investment in the economy thus reduces capital formation domestically. With reduced domestic investment comes a sluggish economic growth and increase in poverty and unemployment. South Africa's GDP growth has been falling in the recent past due to reduced domestic savings amongst other reasons. The severe consequences of indebtedness are that it can affect a person's physical or mental health by causing depression, stress, suicidal thoughts and feeling helplessness and shameful (Fatoki, 2015). It may also become difficult for a person who is failing to pay to obtain a home for rental, employment, new credit, subscription for telephone or internet, pension policies or life insurance (Cuesta \& Budria, 2015). High indebtedness results in high interest rates and high 
principal repayments which may reduce ability of households to cover living expenses. This leads to a decrease in the standard of living and in the end reduces consumer spending, ultimately slowing down economic growth (Schmitt, 2000). This is more so given that over $60 \%$ of Gross Domestic Product (GDP) of South Africa comes from consumption expenditure as shown on Figure 2. The share of consumption on GDP is on the increase as shown on the figure (World Bank 2021).

Figure 2: Households' final consumption expenditure (\% of GDP) in South Africa

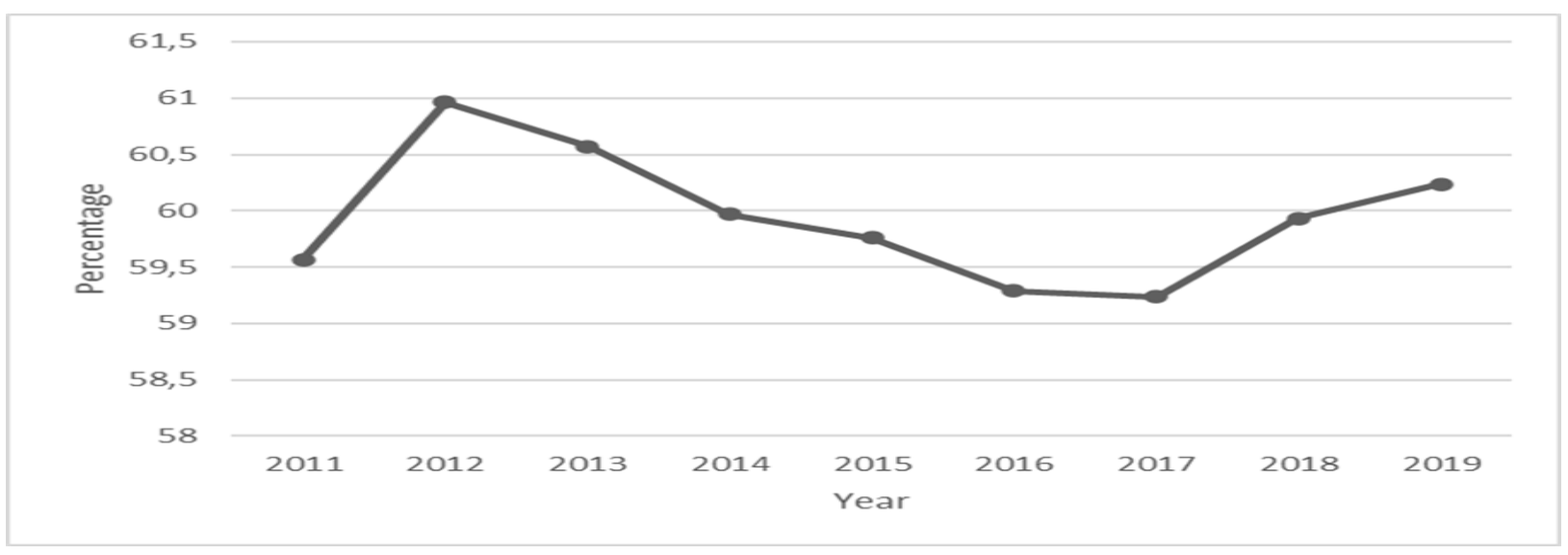

Source: World Bank Development Indicators (2021)

Most of the studies on household debt are from other countries hence there is limited available empirical literature on the household debt in South Africa. This paper is of strategic importance as it provides an extensive overview of the nature and determinants of household debt in South Africa. The paper also presents a framework for managing the household debt in the country.

\section{Methodology}

The objectives of the paper are achieved through systematic literature review, with consideration of both international and South African literature to ensure further understanding of the household debt problem. We made use of systematic literature review method by identifying and synthesising existing literature on household debt in an unbiased way to provide evidence for policymaking. The method provides a clear and comprehensive overview of available evidence on household debt, helps to identify research gaps, and develop new research ideas and helps to identify questions for which the available evidence provides clear answers with no need for further research (Poklepović Peričić \& Tanveer, 2019). Systematic literature review can enhance and promote evidence-informed policymaking, and this is particularly in areas with a strong and well-developed evidence base (Mallett, Hagen-Zanker, Slater \& Duvendack, 2012). In addition to systematic literature review, document analysis and secondary data analysis are also utilised. The paper is based on the life-cycle hypothesis by Modigliani \& Brumberg (1954) and Modigliani (1975), which suggests that households plan their consumption and savings behaviour over their life cycle, they opt for large amounts of debt to smoothen their consumption and for the possession of long-lasting commodities such as houses. The hypothesis also suggest that households have a negative saving rate during the early stage of their working life, but their savings increase while indebtedness decrease as they grow older.

\section{Theoretical Literature}

This section pertains a presentation of theoretical literature and concepts underlying the study. Household debt results when surplus cash balances that are deposited with financial intermediaries are mobilised and transformed into loanable funds for households. The funds get back into circulation as credit to the household sector (Dos Santos, 2009). Harari (2018) differentiates between two types of household debts, namely, secured and unsecured debt. The difference between the two debts lies in the fact that the first uses an asset as security and the latter does not. An example of secured debt could be a mortgage loan, and on the other hand, a student loans is a perfect example of unsecured loan (Harari, 2018). Access to credit helps poor households to escape poverty as they can spend even without current 
income (Cecchetti, Mohanty, \& Zampolli, 2011). When households borrow to finance a more desirable consumption pattern, it becomes as sensible to borrow as it is to save assuming that they have the capacity to service the debt (Bertola, Disney, \& Grant, 2006). When debt is used prudently, it can be an economic determinant of economic growth. Households however become more vulnerable to economic shocks when they borrow beyond their capacity, and this can be worsened by factors such as poor risk management, ineffective legal and institutional infrastructure and weak macroeconomic environment (IMF, 2006).

Over the years, several principles or theories have been developed to explain household debt and these theories have established substantial economic foundations for future researchers. The theories help in understanding why and when households obtain debt. The permanent income hypothesis, which explains some features of consumption states that individuals divide their lifetime resources equally among each period of life (Friedman, 1957). The individual's consumption in each period is not determined by income that period but by income over his/her lifetime, called permanent income and the individuals smoothen consumption expenditure over their life-time income each period. Changes to current income have little effect on current consumption unless the individual believes that the changes have long-term consequences. Transitory income is difference between permanent income and current income and is roughly uncorrelated with permanent income. Individuals can borrow but any outstanding debts are repaid at the end of life. However, time pattern of income is very important to savings and the savings are high when current income is high and negative when current income is less than permanent income. Thus, individuals use saving and borrowing to smooth the consumption path.

The Debt Overhang theory by Sachs (1989) and Krugman (1988) explains that debt overhang is a situation in which either a business, a government, or a household has such high levels of existing debt that they cannot easily borrow more money, even in the case whereby the new borrowing would constitute a good investment that would more than pay for itself (Diamond \& He, 2014). Debt maturity influences debt overhang through reducing incentive for highly levered borrowers to make real investments because some value accrues to debt (Diamond \& He, 2014). Consumer debt delinquencies are a result of a genuine inability to pay as resources become constrained according to the 'cash flow' theory of defaults. The theory assumes that debtors will avoid arrears as long as their income flows are sufficient to cover their debt repayments without undue financial stress (Bhutta et al., 2010). Keynes (1936) developed the absolute income hypothesis where an economic agent will, by nature, consume more as income increases. The key assumption of this theory suggest that consumption is determined by the current levels of income. The marginal propensity to consume (MPC) plays an essential role in Keynesian economics as it measures the consumption-income relation.

The life-cycle hypothesis suggests that individuals plan their consumption and savings behaviour over their life cycle (Modigliani \& Brumberg, 1954; Modigliani, 1975). Households mainly opt for large amounts of debt to smoothen their consumption and for the possession of long-lasting commodities such as houses. A household can maximize utility over its life-time subject to an intertemporal budget constraint. Households intend to smooth out their consumption as efficiently as possible over their entire lifetimes by hoarding when they earn and dissaving when they are retired (Modigliani \& Brumberg, 1954). During the early stage of their working life, households have a negative saving rate, but their savings increase while indebtedness decrease as they grow older (Meniago et al., 2013). Households may then enter into debt in periods where their income is extremely low, to finance their consumption but they repay these loans in period when their income are relatively high (Meniago et al., 2013). When they retire, households again dissave and their consumption is principally financed by the income they earned during their working age. The key assumption of the life cycle hypothesis is that all households choose to maintain stable standard of living. This suggests that they would usually not accumulate a lot in one period to actively spend in the next period. The next section is an analysis of relevant empirical literature.

\section{Empirical literature review on determinants of household debt.}

This section pertains a discussion of previous studies that have been undertaken on determinants of household debt to fulfil paper objectives. An analysis of determinants of household debt is carried out both internationally and in South Africa to enable a deeper understanding of issues under study. The 
financial crisis triggered by the collapse of the United States of America (USA) mortgage market motivated increased empirical studies on household indebtedness (Klein, 2015). From international literature there are conflicting findings on the impact of interest rates. Taylor (2009) concluded that the failure of the USA central bank to increase interest rates in the early 2000s was the main cause of the financial crisis and an over indebted household sector. On the contrary, Sinn \& Valentinyi (2013) found out that the European monetary unification led to low interest rates in Southern Europe, which resulted in a debt boom. Meng, Hoang \& Siriwardana (2013) studied the determining factors of household debt in Australia using the Cointegrated Vector Autoregression (CVAR) model and found interest rates were to be the most significant. They also concluded that housing prices, GDP and the population in the economy have a positive effect on household debt. On the other hand, unemployment rate, inflation, number of new dwellings and inflation were found to have a negative impact on household debt.

Other findings were presented by Turinetti \& Zhuang (2011) who used a linear regression model to investigate the determinants of USA household borrowing. They concluded that unemployment rate, interest rates, disposable personal income per capita, share of retiring population, and educational attainment were negatively related to the household indebtedness in the USA, while housing prices, consumer confidence, and the share of working-age population are positively associated with the household debt. Barba \& Pivetti (2009) analysed the causes and the long-run macroeconomic effects of the increase in household debt in the USA. The rising household debt was presented to be the outcome of growing income inequalities and fluctuations in income distribution in USA. Furthermore, low wages were related to high levels of aggregate demand through household debt. House prices were found to have a positive effect on household debt. Stockhammer \& Wildauer (2018) estimated the determinants of household borrowing using a panel of 13 OECD countries from 1980 to 2011 and concluded that that real estate prices were the most important drivers of household debt.

Rising real estate prices play a major role in household debt accumulation as concluded by Égert, Backé and Zumer (2006) who estimated the determinants of credit to the private sector using simple fixed effects models as well as the mean group estimator. They found a significant and positive effect of house prices on private credit. Similarly, Goodhart \& Hofmann (2008) estimated a panel VAR based on a sample of quarterly data from 1970- 2006 of 17 OECD countries and found out that house prices positively influence private credit and money. Ryoo (2016) used the Minsky model to also conclude that household debt is driven by property prices. Another determinant of debt is income level as concluded by Radipotsane (2007) who studied the determinants of household saving and borrowing in Botswana. Their findings revealed a negative short-run relationship between income and savings as households expect income adjustment to be permanent. The study revealed that households increase consumption more than the increase in their real income implying an increase in household debt and a decline in savings. Kumhof et al., (2012) used a two-class DSGE model to find out the determinants of debt and concluded that poor households are pushed into debt as they try to maintain their consumption levels. However, on the contrary, rapidly growing top incomes lead to rising household debt as consumers imitate the lifestyle and expenses of richer peers (Kapeller \& Schütz, 2014).

Seane et al., (2016) concluded that lack of financial literacy contributes to risk of being indebted and that there is a positive correlation between financial literacy and savings. Thus, households need to have the necessary financial skills to avoid misusing credit and training on financial literacy can take place in schools to stress the importance of good financial management at an early age before debt happens (Seane et al., 2016). Nomatye \& Phiri (2018) aimed at understanding the relationship between household debt and other macroeconomic variables for the South African economy. Using the Quantile Regression methodology, an insignificant relationship between household debt and both consumption and inflation were found. It was also established that GDP growth and house prices were only related at moderate level with household debt while interest rates and investment were found to be related with household borrowing across all quantile distributions. Further, expansion of the banking sector and diversification of its products were also found to contribute to the growth of household debt. In South Africa, Van Der Walt \& Prinsloo (1995) found a positive relationship between household debt and real assets (especially housing), spending on durable goods and consumer prices. 
Generally, South Africans have experienced a rising cost of living resulting in disproportionately large amounts household incomes being commitment to consumption expenditure rather than saving. With increased access to credit, families easily supplement consumption expenditure, increasing debt burden and probability of failure to repay debt (Centre for Social Science Research, 2016). For South Africans, living in urban areas is found to be associated with high debt. The probability of overindebtedness increases significantly with living in an urban area (Nyaruwata, 2009). This is supported Collins (2008) who reports that high indebtedness is found among the high-income groups in urban areas as they have access to financial services. Household disposable income, debt service ratio, household savings, interest rate, consumer price index jointly do Granger cause household debt in South Africa (Seane et al., 2016). However, to the contrary, Kempson et al., (2004), assert that over-indebtedness was much more likely in the poorest areas. Further, the Department for Business Enterprise and Regulatory Reform (2007) observed a persistent reduction in the prevalence of over-indebtedness as income rose. Social grants in South Africa were found to reduce the probability of being over indebted Nyaruwata (2009). However, to the contrary, households relying on social grants for more than 25 percent of their income had a high chance of being over-indebted (Russell et al., 2011). Thus, there is conflicting evidence on the relationship between debt and income level in South Africa.

Over-indebtedness can be triggered by some misfortunes or adverse trigger events often unanticipated such as medical emergencies, or sudden unemployment (Avery, Calem \& Canner, 2004) According to Hurwitz \& Luiz (2007), in such cases South African households are forced to abandon their financial obligations due to emergencies straining their cash flows while on the other side some have a reckless culture of non-payment due to financial illiteracy and lack of education financial literacy. However, Disney et al., (2008), contends that it is not the changes in the debtors' circumstances and massive shifts in earnings that cause delinquencies to occur but the surprise factor and the attempts to survive the immediate consequences. Consumers may be forced to suspending manageable obligations if they realise that continuing to honour them might lead to further deteriorations in their wellbeing (Centre for Social Science Research, 2016).

Households can overestimate the immediate benefits of credit, undervaluing the cost of the debt repayment or inflate expectations of future earnings resulting in them being over- indebted (Heidhues \& Kószegi, 2010; Hoffmann et al., 2012; Bachmann et al., 2015). If families feel that their financial situation is poorer than it should be, they are likely to exercise greater caution when choosing how to spend their money (Centre for Social Science Research, 2016). Lenders also fail to disclose vital information pertaining credit which affects decision to borrow by consumers. Consumers who live or work in environments which highly exposes them to risk will face higher probabilities of delinquency. Due to growing competition in the financial sector, households in South Africa borrow large amounts while meeting less stringent credit application requirements. Lenders have no control over the risks incurred by borrowers with unsecured loans, thereby increasing the likelihood that borrowers will default (Zimunya \& Raboloko, 2015). The predatory practices by lenders are the cause of indebtedness amongst the lowincome groups, not financial illiteracy (Guerin, 2012). There is need for legal mechanisms to help debtors if they find themselves under over indebted situations, in the form of consumption insurance and protection them from creditor actions such as, repossessions, or wage garnishments (Van Apeldoorn, 2008). What is necessary also are sanctions for predatory lending to reduce the propensity for bad loan origination (Goodman \& Smith, 2010; Ho \& Pennington-Cross 2006).

Other studies suggest that over-indebtedness is unavoidable. There is no compelling evidence to suggest that excessive spending is related to consumer debt delinquency, and it is unlikely that there will be enough information to warn lenders of the possibility that debtors will experience economic shock post-consumption. Therefore, it makes sense to accept consumer over-indebtedness as an inevitable feature of the credit system (Centre for Social Science Research, 2016). The occurrence of high household debt can be a cause or a result of poverty (Dubois \& Anderson, 2010). With high servicing costs towards debt a household's disposable income is reduced significantly leading to deprivation materially while on the contrary with poverty households have insufficient income and they become over indebted ending up below the poverty line with continued rising debt. Households that are over-indebted are likely to have a higher rate of basic deprivation (Russell et al., 2011). Debt problems negatively affect the well-being of 
people and well-being is affected more by debt than low income (Howell \& Howell, 2008). Studies on the debt-poverty nexus found a link between low income and over indebtedness (Kempson, 2002; Bryan et al., 2010)

There are studies carried out to find out the relationship between the demographic aspects of household head and debt. On the impact of educational level of the household head on overindebtedness, there are contrasting views. Some evidence suggest that education reduces the probability of over-indebtedness (Bryan et al., 2010). According to Russell et al., (2011) where the head of the household has no educational qualifications, the household is likely to be over indebted. However other literature suggests that having tertiary education increases the probability of over indebtedness (Nyaruwata, 2009). Studies show that the problems of debt decline with age and the 25-35-year age group experiencing the most financial difficulties (Kempson, 2002; Kempson et al., 2004). On the contrary, Nyaruwata (2009) argued that although statistically insignificant, the probability of over-indebtedness increased with age, given that older household heads had more dependents to look after. Bryan et al., (2010) gave an alternative view that age has little impact on the probability of being over-indebted. Biyase \& Fischer (2017) investigated the determinants formal credit in South Africa by low-income households using the Heckman selection model. Their findings revealed that variables such as age of the household head, gender, educational level, employment, race and geographic location of households in South Africa have an impact poor households' propensity to borrow.

There is also a relationship between household characteristics and indebtedness, as there is a lower risk of over-indebtedness when the household owns the house as compared to renting (Kempson et al., 2004). Further, household with mortgage have a higher risk of being overindebted than households who buy outright (Department for Business Enterprise \& Regulatory Reform, 2007; Bryan et al., 2010). Studies also found that tenants are more likely to be overindebted than mortgage holders (Kempson, 2002; Kempson et al., 2004; Department of Trade and Industry, 2005; Russell et al., 2011). As expected, a household larger in size has a higher probability of being over-indebted (Nyaruwata, 2009; Bryan et al., 2010). Studies on the relationship between family circumstances and over indebtedness concluded that family events such as having a baby or a breakdown in relationship increased the likelihood of overindebtedness (Department of Trade and Industry, 2005). This can be attributed to increased costs or reduced income that comes as a result. Other studies suggest that divorce or separation or being a lone parent increase probability of over indebtedness (Russell et al., 2011; Bryan et al., 2010). On the contrary, Kempson et al., (2004) found no significant association between over-indebtedness and separation or having a new baby. Literature also suggest that female-headed households are more likely to be overindebted than male-headed households possibly since they work fewer hours and get less incomes as they have maternal responsibilities (Russell et al., 2011; Department of Trade and Industry, 2005). Where the household head is not working, is sick or disabled, over indebtedness is likely to be experienced (Russell et al., 2011). The next section gives the results of the study.

\section{Results}

The problem of household over-indebtedness in South Africa affects the well-being of households as well as economic performance of the country. Despite the fall in household debt to disposable income ratio over the years, the ratio is now on an upward trajectory since 2018, with unsecured debt increasing faster than household disposable income. Hence some measures are necessary to address growth in household debt. Several findings are made from the paper on nature and determinants of household debt in South Africa. Mortgages constitute most of the debt held, at $52 \%$ of debt followed by secured credit agreements. The least held debt is short-term credit at $0.2 \%$. Thus, policies to address growth of debt should target mostly mortgages and secured credit agreements. Results suggest that households with a mortgage have a higher risk of being overindebted than households who buy outright. Further, households in South Africa are indebted because they lack the necessary financial skills. They need upskilling on financial skills to avoid overborrowing or misusing credit. Debtors lack proper protection from the predatory practices by lenders which cause indebtedness. Further, expansion of the banking sector and diversification of its products are found to contribute to the growth of household debt. Thus, sanctions are needed for predatory lending to reduce the propensity for bad loan origination. Lenders should disclose vital information pertaining credit which affects decision to borrow by consumers. Other 
factors related positively to indebtedness are rising cost of living and low household disposable income, low household savings, high interest rates and consumer price index. Some misfortunes or adverse trigger events have also been found to trigger over indebtedness while some shifts in earnings can cause delinquencies to occur.

There are conflicting results from literature pertaining causes of over-indebtedness. Some results suggests that indebtedness increases significantly with living in an urban high-income area, as there is access to financial services. However, on the contrary other results suggest that over-indebtedness is much more likely for poor households due to low incomes. There is also conflicting evidence on relationship between education and age with respect to debt. Results from some literature suggests having education or being older in age reduces the probability of over-indebtedness while other literature suggest that having tertiary education or being older in age increases the probability of over-indebtedness. There are also conflicting results on social security grants as some literature concludes that the grants reduce the probability of being over indebted while other literature suggests that households relying on social grants for more than $25 \%$ of their income have a high chance of being over-indebted. Findings also suggest that female-headed households and households where head is not working, is sick or disabled are more likely to be over-indebted. The risk of over-indebtedness is lower for households that own the house as compared to renting. Life events such as having a baby or a breakdown in relationship increase the debt likelihood. Large households have a higher probability of being over-indebted and tenants are more likely to be over-indebted than mortgage holders.

\section{Recommendations on managing household debt}

From the review of literature, a framework for managing household debt in South Africa is developed. The framework has 4 components as shown in Figure 3 namely upskilling households, review of interest rates, information disclosure by moneylenders and availability of insurance. These components are a summary of measures that can be implemented to reduce household debt. South Africa was found to have the lowest number of economically literate people, and second lowest number of financially literate people from a survey, meaning that there is need to upskill households to ensure they have necessary skills and knowledge to manage finance through the NCA (No. 34 of 2005).

Figure 3: A framework for managing household debt in South Africa

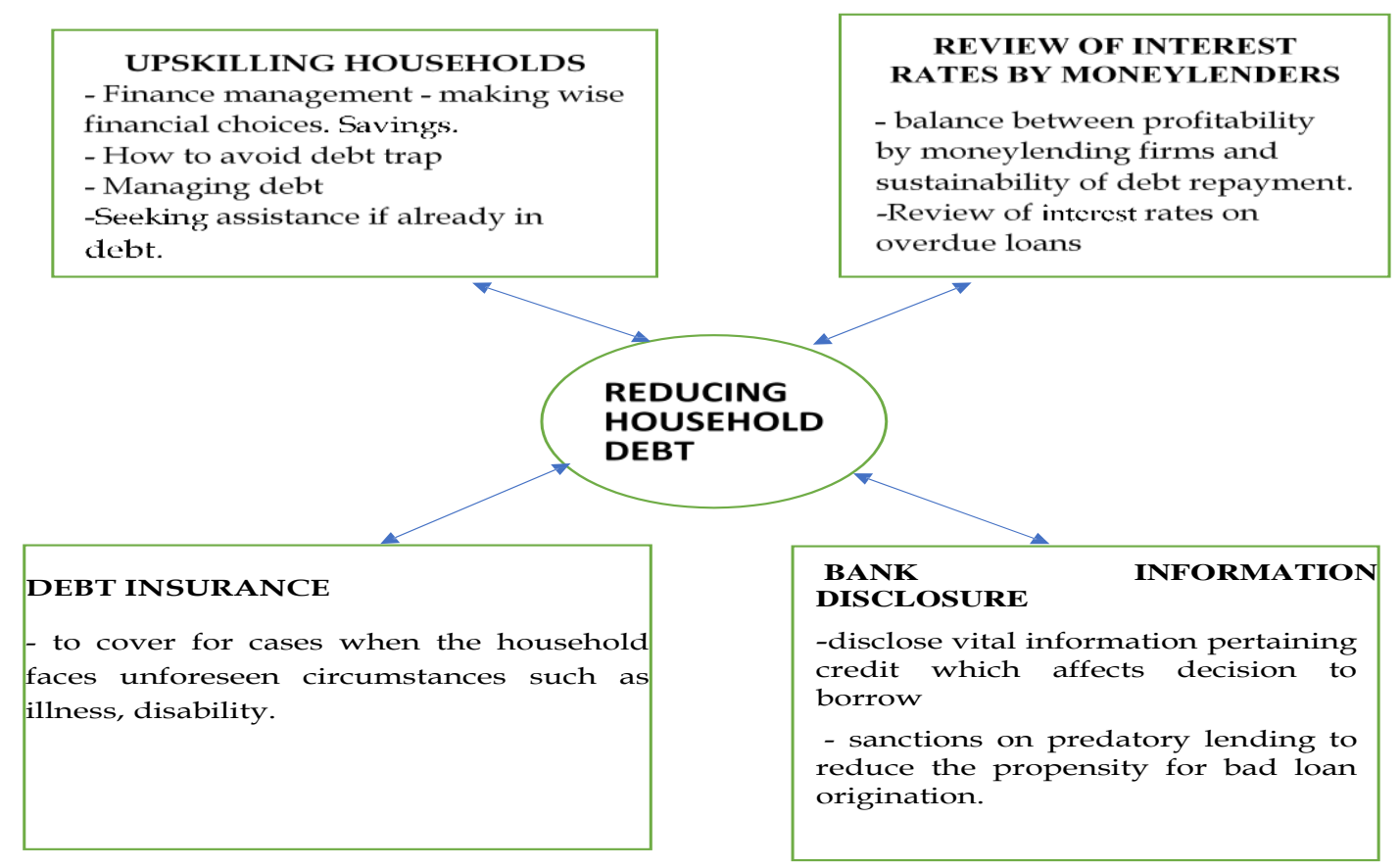

Source: Author's compilation using results 
Although several programmes and initiatives were implemented to educate citizens on debt, the initiatives have not been very effective judging by debt-to-income ratio. This calls for participation by different stakeholders to support the NCR such as learning institutions in assisting households to understand how to effectively manage their finances and debt. Findings suggest that there are both demand and supply-side factors that account for the high household debt in South Africa. Therefore, there is need to address these factors. As money lending institutions expand and diversify their products, they need to be wary of impact on growth of household debt. Thus, it is important for them to disclose vital information pertaining credit which affects decision to borrow by consumers. Thus, predatory lending should be discouraged, and debt contracts should not be vague.

Another issue to be considered is that of interest rates on debt repayment and on overdue repayments. Moneylending firms need to consider a review of interest rates to make a balance between their profitability and sustainability of debt repayment by households. Thus, it may help to reduce household debt if the firms charge affordable interest on loans. Debt or consumption insurance on all loans to cover for cases when the household faces unforeseen circumstances such as illness, disability may also help relieve households from the debt burden. Thus, moneylenders need to work with insurance companies to enable debt insurance to protect debtors. There is need for legal mechanisms by the Government of South Africa to protect and help debtors if they find themselves under over indebted situations. Above all, households need to practice responsibility by gathering information and considering ability to repay before borrowing.

\section{Conclusions}

We conclude that mortgages constitute most of the household debt in South Africa. There are several causes of over-indebtedness of households. These include lack of financial literacy and lack proper protection from the predatory practices by lenders which cause them to enter into debt without considering the impact and affordability. The increasing cost of living coupled with low household disposable income leads to low or no savings leading to household increased debt. Other causes are high interest rates and misfortunes or adverse trigger events. Household debt is also affected positively or negatively by educational level, gender, age, health and employment status of the household head, whether the household is renting, has a mortgage or whether it receives a social security grant and household size. The measures to reduce household debt in South Africa are upskilling households on financial literacy, review of interest rates on debt, information disclosure by moneylenders and availability of insurance for debtors.

\section{Contribution to knowledge and implications for different stakeholders}

This paper contributes to new knowledge as it explains the nature of household debt and comes up with a new framework on how best to manage household debt, using the case of South Africa. This framework can be adopted by stakeholders concerned to help households lessen the burden of debt. There are implications for different stakeholders emanating from the paper. These include learning institutions and their role in upskilling financial literacy and debt management skills as well as banks and moneylenders on ensuring information disclosure and review of interest rates. Insurance companies have a role in providing debt or consumption insurance and the government's role is ensuring legal mechanisms to help and protect over indebted households. The households need to act more responsibly and seek more information to avoid falling into the debt trap.

\section{Limitations and direction for future research}

The limitation faced is that literature on household debt with specific reference to South Africa is not widely available. In future, research may focus on econometric analysis of variables that affect debt in South Africa and in depth understanding the characteristics of household debt.

\section{References}

Allen, F., Babus, A. and Carletti, E. (2009). Financial Crises: Theory and Evidence, Annual Review of Financial Economics, Vol. 1:97-116. First published online as a Review in

https://doi.org/10.1146/annurev.financial.050808.114321.

Avery, R. B., Calem, P. S. \& G. B. Canner. 2004. Consumer credit scoring: Do situational circumstances matter? Journal of Banking \& Finance, 28(4): 835-856. 
Barba, A., \& Pivetti, M. (2009). Rising Household Debt: Its Causes and Macroeconomic

Implications - A Long Period Analysis. Cambridge Journal of Economics, 33, 113-137.

http://dx.doi.org/10.1093/cje/ben030.

Bertola, G., Disney, R., \& Grant, C. (2006). The Economics of Consumer Credit Demand and Supply. In G. Bertola, R. Disney, \& C. Grant (Eds.), The Economics of Consumer Credit (pp. 1-26). Cambridge, Massachusetts: MIT Press.

Bhutta, N., Dokko, J. \& H. Shan. 2010. The depth of negative equity and mortgage default decisions. Board of Governors of the Federal Reserve System (US), New York (No. 2010-35).

Biyase, M. \& Fisher, B. (2017). Determinants of Access to Formal Credit by the Poor Households. Studia Universitatis Babes-Bolyai. Economica.62.10.1515/subboec-2017-0004.

Bryan, M., Taylor, M. \& Veliziotis, M. 2010. Over-indebtedness in Great Britain: An Analysis Using the Wealth and Assets Survey and Household Annual Debtors Survey, London: University of Sussex.

Cecchetti, S. G., Mohanty, M. S., \& Zampolli, F. (2011). The Real Effects of Debt. In Bank for International Settlements. Working Paper No. 352.

Centre for Social Science Research. (2016). University of Cape Town http://cssr.uct.ac.za/pub/wp/368/ ISBN: 978-177011-355-8.

Collins, D. 2008. Debt and household finance: Evidence from the Financial Diaries. Development Southern Africa, 25(4), 469-479.

Cuesta, M.B. \& Budria, S. 2015. The Effects of Over-Indebtedness on Individual Health. IZ A Discussion Paper No. 8912, Institute for the Study of Labour.

Diamond, D.W. \& He, Z. (2014). A Theory of Debt Maturity: The Long and Short of Debt Overhang, The Journal of Finance, Volume 69, Issue 2, Wiley Online library.

Disney, R., Bridges, S. \& J. Gathergood. 2008. Drivers of over-indebtedness. Nottingham: Centre for Policy Evaluation, University of Nottingham.

Dos Santos, P. L. (2009). At the Heart of the Matter: Household Debt in Contemporary Banking and the International Crisis. Ekonomiaz, 72(3).

Dubois, H. \& Anderson, R. 2010. Managing household debts: Social service provision in the EU. Working paper No. $\mathrm{EF} / 10 / 70$, Eurofond

Égert, B., Backé, P., and Zumer, T. (2006). Credit growth in central and eastern Europe. ECB working paper No 687.

Fatoki, O. 2015. The causes and consequences of household over-indebtedness in South Africa. Journal of Social Science, 43(2), 97-103.

Frieman, M. (1957). A theory of the consumption function: a study by the National Bureau of Economic Research. Princeton, NJ: Princeton University.

Goodman, A. C. \& B. C. Smith. 2010. Residential mortgage default: theory works and so does policy. Journal of Housing Economics, 19(4): 280-294.

Grant, C. 2010. Shocks and the debt repayment behaviour of households in the EU. http://www.southampton.ac.U'K./ mkwiek/WIEM2010/Grant- Probit FE.pd Accessed 4 April 2012.

Guerin, I. 2012. Households' Over indebtedness and the Fallacy of Financial Education: Insights from Economic Anthropology. Microfinance in Crisis: Working Paper 2012-1, Paris 1 Sorbonne University.

Harari, D. (2018). Household debt: statistics and impact on economy. House of Commons Briefing Paper 7584.

Hurwitz, I. \& Luiz, J. 2007. Urban working-class credit usage and over-indebtedness in South Africa. Journal of Southern African Studies, 33(1), 107-131.

International Monetary Fund (IMF), (2006). Household Credit Growth in Emerging Market Countries (Chapter 2). In Global Financial Stability Report: Market Development and Issues. Washington: International Monetary Fund.

Jappelli, T. (2010) Economic literacy: An international comparison, Centre for financial studies (CFS), Working paper no. 16 , pp. $1-37$.

Kapeller, J., Schütz, B. (2014): Debt, boom, bust: a theory of Minsky-Veblen cycles. Journal of Post Keynesian Economics, 36 (4), pp. 781-814.

Kempson, E. 2002. Over-indebtedness in Britain - A Report to the Department of Trade and Industry. London: Department of Trade and Industry.

Kempson, E., McKay, S. \& Willitts, M. 2004. Characteristics of Families in Debt and the Nature of Indebtedness Research Report No 211. Leeds: Department for Work and Pensions.

Keynes, J. (1936). The General Theory of Employment, Interest and Money. London: Macmillan.

Klein, M. (2015). Inequality and household debt: A panel cointegration analysis. Empirica 42, no. 2: $391-412$.

Krugman, P. 1988. Financing vs. forgiving a debt overhang: Some analytical notes. Working paper No. 2486, National Bureau of Economic Research.

Business Tech, (2018). https://www.businesslive.co.za/bt/money/2019-01-28 fewer-credit-agreements-yet-sasconsumers-still-drowning-in-debt. Accessed 05 April 2021. 
Kumhof, M., Lebarz, C., Rancière, R., Richter, A.W. and Throckmorton, N.A. (2012) Income Inequality and Current Account Imbalances, IMF Working Paper, Research Department

https://www.imf.org/external/pubs/ft/wp/2012/wp1208.pdf. Accessed 22 April 2021.

Mallett, R., Hagen-Zanker, J., Slater, R. \& Duvendack, M. (2012) The benefits and challenges of using systematic reviews in international development research. Journal of Development Effectiveness, 4:3, 445-455, DOI:10.1080/19439342.2012.711342.

Meng, X., Hoang, N. T. \& Siriwardana, M. (2013). The determinants of Australian household debt: A macro level study. Journal of Asian Economics. Elsevier, vol. 29(C), pages 80-90.

Meniago, C., Mukuddem-Petersen, J., Petersen, M. A., \& Mongale, I. P. (2013). What causes household debt to increase in South Africa? Economic Modelling, Volume 33, Pages 482-492 Elsevier.

Modigliani, F. \& Brumberg, R.H. (1954). Utility Analysis and the Consumption Function: An Attempt at Interpretation. Post-Keynesian Economics, New Jersey: Rutgers University Press.

Modigliani, F. (1975). "The life-cycle hypothesis of saving twenty years later", in Michael Parkin, ed., Contemporary Issues in Economics, Manchester. Manchester University Press. pp. 2-35.

Mutero, A. (2014). Household debt and consumption spending in South Africa: an ARDL bounds testing approach. Bank and Bank System, 9(4), pp. 73-81.

National Credit Act (2005) Government Gazette no.34 of 2005, 489 (28619).

National Credit Regulator (2016a) Consumer Credit Market Report - First Quarter: March 2016. Midrand: National Credit Regulator.

National Credit Regulator (NCR). (2012). Research on the increase of unsecured personal loans in South Africa's credit market: Final report. 6 August.

National Credit Regulator (2014) Annual Report.

Nomatye, A. \& Phiri, A., (2018). Investigating the Macroeconomic Determinants of Household Debt in South Africa. International Journal of Economics and Financial Issues, 8(2), 62-69.

Nyaruwata, G. 2009. Addressing over-indebtedness in South Africa: What role should supply-side and demand-side interventions play? Unpublished master's thesis. Cape Town: University of Cape Town.

Poklepović Peričić, T. and Tanveer, S. (2019). Why systematic reviews matter, A brief history, overview and practical guide for authors. Elsevier Connect.

Russell, H., Maitre, B. \& Donnelly, N. 2011. Financial Exclusion and Over-indebtedness in Irish Households. Social Inclusion Research Report No. 1. Dublin: Department of Community, Equality \& Gealtacht Affairs and Economic and Social Research Institute.

Ryoo, S. (2016). Household debt and housing bubbles: A Minskian approach to boom-bust cycles. Journal of Evolutionary Economics 26, no. 5: 971-1006.

Sachs, J. 1989. The Debt of Overhang of Developing Countries. In Debt Stabilization and

Development: Essays in Memory of Carlos Diaz-Alejandro.

Seane, S.T., Mah, G. and Saah, P. (2016). Risk, opportunities and reasons of the household debt changes: the case of an emerging economy. Risk Governance \& Control: Financial Markets E Institutions / Volume 6, Issue 4, Fall 2016, Continued-1

Sinn, H. W. \& Valentinyi, A. (2013). European Imbalances. voxeu.org. Available at:

www.voxeu.org/article/european-imbalances (Accessed April 9, 2020).

Stockhammer, E. \& Wildauer, R. (2018) Expenditure Cascades, Low Interest Rates, Credit Deregulation or Property Booms? Determinants of Household Debt in OECD Countries. Kingston University and University of Greenwich.

Taylor, J. B. (2009). The financial crisis and the policy responses: An empirical analysis of what went wrong. National Bureau of Economic Research, Working paper 14631.

doi 10.3386/w14631

Trading Economics (2020). Available: https://tradingeconomics.com/South Africa/households-debt-to-income. Accessed 20 March 2021.

Turinetti, E., \& Zhuang, H. (2011). Exploring Determinants of U.S. Household Debt. Journal of Applied Business Research (JABR), 27(6), 85-92. https://doi.org/10.19030/jabr.v27i6.6468.

Van Apeldoorn, J. C. 2008. The 'fresh start' for individual debtors: social, moral and practical issues. International insolvency review, 17(1): 57-72.

World Bank Development Indicators (2021) https://databank.worldbank.org/source/world-developmentindicators\#

accessed 21 April 2021.

Zimunya \& Raboloko (2015) Determinants of Household Debt in Botswana, Journal of Economics and Public Finance. Vol. 1, No. 1, ISSN 2377-1038 (Print) ISSN 2377-1046. 